\title{
Evaluation of Green Port Factors and Performance: A Fuzzy AHP Analysis
}

\author{
Rong-Her Chiu, ${ }^{1}$ Le-Hui Lin, ${ }^{1}$ and Shih-Chan Ting ${ }^{2}$ \\ ${ }^{1}$ Department of Shipping and Transportation Management, National Taiwan Ocean University, Keelung 20224, Taiwan \\ ${ }^{2}$ Department of Transportation Science, National Taiwan Ocean University, Keelung 20224, Taiwan \\ Correspondence should be addressed to Le-Hui Lin; hrylin@ms51.hinet.net
}

Received 4 October 2013; Revised 20 December 2013; Accepted 20 December 2013; Published 12 January 2014

Academic Editor: Ching-Ter Chang

Copyright (c) 2014 Rong-Her Chiu et al. This is an open access article distributed under the Creative Commons Attribution License, which permits unrestricted use, distribution, and reproduction in any medium, provided the original work is properly cited.

\begin{abstract}
Due to the occurrence of abnormal global environmental change, the concept of sustainable development becomes more and more important. Port plays an important role in economic development for a country. To tackle the environmental pollution coming from the construction and operation of a port, the green concept emerged as a solution. Founded on the previous literatures, the current study formulates a Fuzzy AHP model including five dimensions and thirteen factors as the guidelines for green port operation. The results of empirical study point out the top five priority attributes of green port operation which are: hazardous waste handling, air pollution, water pollution, port greenery, and habitat quality maintenance. The FAHP model is a good referral for decision makers of port organizations to forge a "greener" port operation; it also can be used to evaluate the port's green operation performance.
\end{abstract}

\section{Introduction}

Maritime transport is the backbone of international trade and a key engine driving globalization. Around 80 percent of global trade by volume and over 70 percent by value are carried by sea and are handled by ports worldwide in 2012; these shares are even higher in the case of most developing countries. As freight traffic continues to grow, the question of how to ensure the long-term sustainability of such growth is playing an increasingly important part in the policy debate on globalization, trade and development, environmental sustainability, energy security and climate change [1]. Due to the abnormal global environmental change, we face serious problem such as global warming, water pollution, waste disposal, air pollution, ozone depletion, space extinction, and rapid consumption of energy issue. The concept of sustainable development was advocated to mitigate the continued destruction to the Earth.

Sustainability can be defined as "a process of change in which the exploitation of resources, the direction of investments, the orientation of technological development, and institutional change are all in harmony and enhance both current and future potential to meet human needs and aspirations; that is, meeting the needs of the present without compromising the ability of future generations to meet their own needs" $[2,3]$. In essence, sustainable development recognizes the interdependence of environmental, social, and economic systems and promotes equality, justice, and global citizenship $[4,5]$. Besides, sustainable development is considered to encompass the so-called triple bottom line which includes (1) ecological balance (including health of natural ecosystems, depleting feedstocks, and climate change), (2) sustained economic stability, and (3) social development and equity $[2,6]$.

Seaports connect the world through maritime transportation networks, promote international trade, and support global economic growth. They can also be the checkpoint for anthropogenic inputs of environmental pollution through maritime transportation activities, which presents new and critical challenges to port managers regarding the provision of efficient port services and utilization of their unique position to curb global environmental problems [7]. To tackle the environmental pollution coming from the construction and operation of a port, the sustainable development and green concept operation emerged as a requirement and solution. The green concept basically introduces three aspects in-port 
operation and development planning including energy conservation, environmental protection, and ecology care $[8,9]$.

Indeed, to emphasize the green concept for protecting our environment is important; the even more significant matter is how to promote the green concept into action. This research tries to accomplish this task. The major purpose of this paper is to investigate the factors for operating a green port. Analytical Hierarchy Process (AHP) methodology is used to analyze the importance and priority of green port factors; then Fuzzy AHP is employed to assess the green port performance of three empirical cases. This study firstly reviews various green port factors. Then, rules of Fuzzy AHP are briefly introduced. Thirdly, an AHP questionnaire is designed to collect empirical data from port industries for pointing out the importance and priority of green port factors; the criteria then are used to evaluate three ports' performance. Finally, some conclusions are presented.

\section{Literature Review}

The "duo" system of sea transport includes ships and ports [10]; "duo" means that ships and ports are the two main parts of the maritime transport. Potential environmental impacts not only come from in-port operations, but also the maritime activities and in-land transport. Therefore, some previous studies on shipping operations are reviewed due to their close relationship with port operations.

2.1. Maritime Shipping and Environment. United Nations' study points out that maritime transport is not insulated from climate changes; the type, range, and magnitude of impacts vary according to local conditions, transportation systems, designs, and policies, as well as the capacity to adapt and minimize the costs. Direct impacts are likely in relation to maritime transport infrastructure, operations, and maintenance. Maritime transport services may also be affected indirectly, as a result of changes in demand, induced by climate change effects on trade, investment decisions, demographics, agricultural production, forests, energy exploration, energy demand, and fishing activity [11].

To reduce environmental impacts, emissions from commercial shipping have been one of the important subjects under intense scrutiny. According to Psaraftis and Kontovas [12], there are three main ways to reduce maritime greenhouse gas (GHG) emissions. Firstly, technical measures include more efficient ship hulls, energy-saving engines, more efficient propulsion, use of alternative fuels, such as fuel cells, biofuels, or others, "cold ironing" in-ports (providing electrical supply to ships from shore sources), devices to trap exhaust emissions (such as scrubbers), and others, even including the use of sails to reduce power requirements. Secondly, the market-based instruments measures are classified into two main categories, emissions trading and carbon levy schemes. Thirdly, there are operational options that mainly involve speed optimization, optimized routing, improved fleet planning, and other logistics-based measures.

For assessing a cost-effectiveness of technical and operational measures for reducing $\mathrm{CO}_{2}$ emissions from shipping,
Eide et al. [13] propose a methodology for assessing the cost-effectiveness of technical and operational measures for reducing $\mathrm{CO}_{2}$ emissions from shipping through the development of an evaluation parameter and decision criterion. The methodology is in line with the Intergovernmental Panel on Climate Change (IPCC) and with regulatory work on safety and environmental protection issues at the International Maritime Organization (IMO).

Comparing the ISO 50001 and the International Safety Management (ISM) code on ship energy efficiency management plan for reducing $\mathrm{CO}_{2}$ emissions, Johnson et al. [14] discover that the Ship Energy Efficiency Management Plan (SEEMP) lacks crucial features found in typical management system standards, such as requirements on policy and management reviews. Moreover, best-practice in the form of the ISO 50001 addresses important aspects, such as monitoring, energy auditing, design, and procurement processes in much more detail. In practice, speed reduction is a very popular operational measure to reduce fuel consumption for saving costs and to curb emissions. In order to maintain the same schedule arranged by shipping company, ports should propose new measures to reduce port service time (through minimizing disruption and maximizing efficiency) for compensating ship's longer time spending at sea due to slow steaming [15]. Again, Woo and Moon [16] explore the effects of slow steaming on the environmental performance in liner shipping. By using simulation technique, they found out the following results: (1) slow steaming is helpful in reducing the amount of $\mathrm{CO}_{2}$ emissions, whereas it is not always useful to reduce the operating costs. As the voyage speed decreases, more $\mathrm{CO}_{2}$ emissions can be reduced. However, the operating cost can be reduced only within the range between 25 and 13.6 knots by slow steaming, and it can be minimized at 18.6 knots, (2) the enlargement of vessel size on a loop is helpful to reduce the amount of $\mathrm{CO}_{2}$ emissions at all different voyage speeds. However, this influences the operating costs and the costenergy efficiency (CEEI index) negatively; (3) when considering the current average voyage speed (15-17 knots), it can be evaluated that more than $90 \%$ of $\mathrm{CO}_{2}$ emissions have been reduced already on the Asia/Europe route based on the results of the simulation, and finally (4) three strategic voyage speeds were derived by simulation, with the optimal voyage speed being 17.4 knots. At the optimal voyage speed, liners can maximize the reduction of $\mathrm{CO}_{2}$ emissions at the lowest operating cost, thus satisfying the political target of IMO.

2.2. Green Port Factors. Studies on the environmental issues related to ports are rather diverse. In recent years, a major concern for port operations has been the minimization of environmental effects. Ports have been trying to attain a "greener" status by introducing new technologies and renewing their infrastructure while avoiding unnecessary energy use. The port is considered as a system comprising several different parts, all of which contribute to its environmental footprint. These can be segregated to maritime activities, inport operations and in-land transport. As transport activity has increased, so have its undesirable side effects including air pollution, noise pollution, $\mathrm{CO}_{2}$ emissions, and congestion. 
The creation and expansion of transport infrastructures like ports, roads, railways, and airports have the potential to cause serious environmental damage [17]. Therefore, the green concept is gaining support as a way to develop and operate port businesses to prevent the environmental degradation, biodiversity loss, and unsustainable natural resource use.

According to the study by OECD [18, 19], wellfunctioning ports can play an important role in promoting economic development in the surrounding regions and a wider hinterland; however, port activities can have significant negative impacts on the environment. Sea transport operation causes environmental impact both in-ports, as well as in the immediate vicinity of the ports. Examples of these impacts are noise from ship engines and machinery used for loading and unloading, exhausts of particles, $\mathrm{CO}_{2}, \mathrm{NO}_{x}$, and $\mathrm{SO}_{2}$ from the ship's main and auxiliary engines, and dust from the handling of substances such as grain, sand, and coal. Road and rail traffic to and from the port area cause additional environmental problems. In general, the environmental impact of ports may be divided into three subcategories: (1) problems caused by port activity itself; (2) problems caused at sea by ships calling at the port; and (3) emissions from intermodal transport networks serving the port hinterland. Due to the wide range of these impacts, a broad mix of policy instruments needs to be applied to manage environmental impacts, and the "optimal" mix of instruments is likely to vary much from port to port.

Referring to the reports of American Association of Port Authorities, Bailey and Solomon [20] pointed out that due to the fact that seaports were often situated in or near residential communities and/or environmentally sensitive estuaries, the following environmental concerns were commonly mentioned: (1) air pollution from port operations, including smog and particulate pollution, (2) loss or degradation of wetlands, (3) destruction of fisheries and endangered species, (4) wastewater and stormwater discharges, (5) severe traffic congestion, (6) noise and light pollution, (7) loss of cultural resources, (8) contamination of soil and water from leaking storage tanks, (9) air releases from chemical storage or fumigation activities, (10) solid and hazardous waste generation, (11) soil runoff and erosion, and so forth. They concluded that numerous approaches would be necessary to reduce pollution for ports moving toward a sustainable operational model that serves a local region without damaging the health and integrity of local communities and ecosystems.

Darbra et al. [8] discovered that significant environmental aspects in sea ports are (1) emissions to air (including gases, solid particles, and energy; dust is a significant contribution), (2) discharges to water (e.g., waste waters, accidental releases during loading/unloading operations), (3) releases to soil due essentially to industrial activities, (4) releases to marine sediments and activities affecting the seabed (such as dredging), (5) noise (with its potential impact on population and fauna), (6) waste generation and dredging disposal, (7) loss/degradation of terrestrial habitats, (8) changes in marine ecosystems, (9) odours, (10) resource consumption, and (11) port development (land and sea occupation). The study by Peris-Mora et al. [9] also indicated that 21 port activities in industrial ports can cause a total of 63 forms of potential environmental impact, which is necessary to apply and improve the control over these activities to reduce the magnitude of the problem. These environment impacts can be classified as air pollution, noise pollution, odour pollution, water pollution, soil pollution, waste creation (urban waste and dangerous waste), resource consumption, and others. Focusing on Poland, Klopott [21] points out the top ten environmental priorities of three Polish ports in 2012 which are (1) ship waste (sewage), (2) noise, (3) dust, (4) dredging (disposal), (5) port development (land), (6) conservation areas, (7) ballast water, (8) ship exhaust emission, (9) energy consumption, and (10) relationship with local community.

Considering that most of the studies on maritime pollution control were focusing on technical designs and operating issues over deep sea shipping, study of Homsomba et al. [22] reveals that in the absence of interport coordination, pollution spill-over and interport competition can lead to distorted pollution taxation and emission constraints. Therefore, they call for regional ports to coordinate their pollution control efforts despite the fact that there is potential competition among the ports in a region. Based on Korean ports' data, Chang [23] employs Data Envelopment Analysis (DEA) to study the undesirable outputs that ports generate, that is, $\mathrm{CO}_{2}$ emissions. He analyzes the environmental efficiency of ports in Korea and to estimate the potential $\mathrm{CO}_{2}$ emission reduction by ports in the country. The study discovers that Korean ports are deemed to be economically inefficient, but environmentally efficient when considering economic and environmental performances simultaneously.

Previous studies mentioned above present a wide diversity of research directions about the different aspects of green port issues. Types of pollution is the most popular topic being covered by Darbra et al. [8], Peris-Mora et al. [9], Tull [17], Braathen [18], OECD [19], Bailey and Solomon [20], and Klopott [21]; some of the studies also point out the sources of pollution. Facing the various types of pollution, most of the studies suggest some control instruments and indeed many port authorities in the world also set up goals and implement measures to mitigate the environmental impacts within their ports [24]. However, few studies investigate how a port can choose environmental control measures according to the importance priority of the green port factors; this study tries to fill the gap. Through reviewing academic papers and many port authorities' green port or environmental policy documents, Chiu and Lai [24] identified 12 types of green port measures. These measures may be classified into five dimensions including environmental quality, use of energy and resource, waste handling, habitat quality, and greenery, as well as social participation.

To implement those measures (including air pollution, water pollution, noise pollution, land and sediments pollution, materials selection, water consumption, energy usage, general waste handling, hazardous waste handling, habitat quality and greenery, community promotion, and education, as well as port staff training), many detailed actions may be taken to achieve the goal of building up and operating a green port. Undoubtedly, it would be difficult to require every port authority to implement all the actions to achieve green port condition. It should be a progressive process to execute the 
green port actions. Therefore, the green port measures need further investigation about their importance and priority for achieving "greener" status. The methodology of Analytic Hierarchy Process (AHP) proposed by Saaty (1977) [25], which was improved by introducing fuzzy concept and called Fuzzy AHP, consequently can be used to identify the relative importance of green port factors. Practically, if a port cannot implement all the green measures, the port authority may choose some prioritized items for implementation in the first stage and then gradually fulfill the entire green port operation.

\section{Methodology}

3.1. Analytical Hierarchy Process (AHP). Analytic Hierarchy Process (AHP) is a popular technique often used to model subjective decision-making processes based on multiple attributes $[25,26]$. From that moment on, it is being widely used in corporate planning, portfolio selection, benefit/cost analysis by government agencies for resource allocation purposes, and location choice of international logistics center [27]. The procedure for AHP can be summarized in four steps as follows.

Step 1. Set up the hierarchy system by decomposing the problem into a hierarchy of interrelated elements.

Step 2. Generate input data consisting of pairwise comparison matrix to find the comparative weight among the attribute of the decision elements.

Step 3. Synthesize the judgment and estimate the relative weight.

Step 4. Determine the aggregating relative weights of the decision elements to arrive at a set of ratings for the decision alternatives/strategies.

3.2. Fuzzy Analytic Hierarchy Technique. The fuzzy AHP technique can be viewed as an advanced analytical method developed from the traditional AHP. In the conventional AHP, the pairwise comparisons for each level with respect to the goal of the best alternative selection are conducted using a nine-point scale. So, the application of Saaty's AHP has some shortcomings, such as (1) the AHP method is mainly used in crisp decision applications; (2) the AHP method creates and deals with a very unbalanced scale of judgment; (3) the AHP method does not take into account the uncertainty associated with the mapping of one's judgment to a number; (4) ranking of the AHP method is rather imprecise; and (5) the subjective judgment, selection, and preference of decision-makers have great influence on the AHP results. Besides, a decisionmaker's requirements on evaluating alternatives always contain ambiguity and multiplicity of meaning. Furthermore, it is also recognized that human assessment on qualitative attributes is always subjective and thus imprecise [28].

Due to the existence of vagueness and uncertainty in judgments, a crisp, pairwise comparison with a classical AHP may be unable to accurately represent the decision-makers'

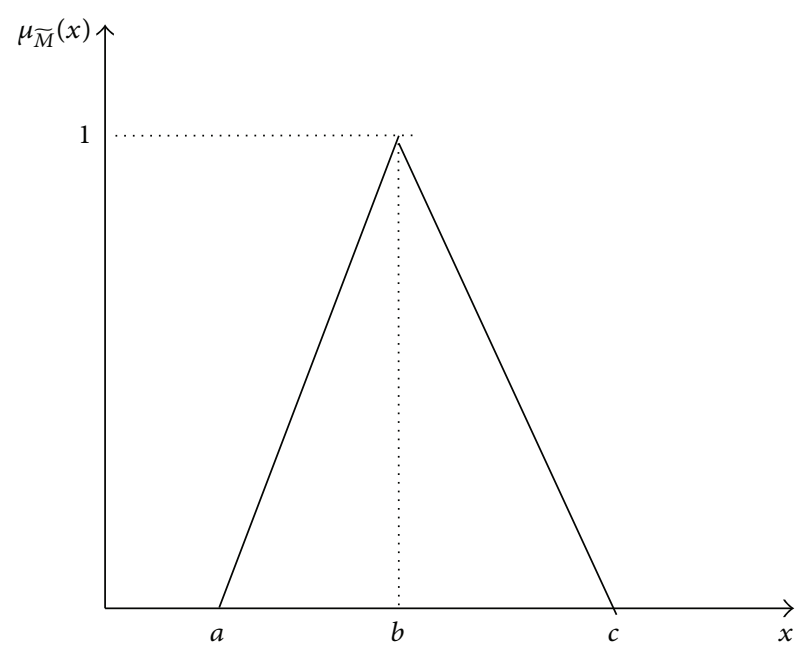

FIgURE 1: Triangular fuzzy number.

ideas. Although the discrete scale of AHP has the advantages of simplicity and ease of use, it is not sufficient to take into account the uncertainty associated with the mapping of one's perception to a number. Therefore, fuzzy logic is introduced into the pairwise comparison to deal with the deficiency in the classical AHP, referred to as Fuzzy AHP (FAHP). FAHP is an efficient tool to handle the fuzziness of the data involved in deciding the preferences of different decision variables. The comparisons made by experts are represented in the form of triangular fuzzy numbers to construct fuzzy pairwise comparison matrices [29].

Fuzzy set theory was proposed by Zadeh [30] to deal with the vagueness of linguistic variables. A fuzzy number is a special fuzzy set $F=\left\{\left(x, \mu_{F}(x)\right), x \in R\right\}$, where $x$ fuzzy set $F=x, \mu_{F}(x), x \in R$, where $x$ takes its value on the real line, $R:-\infty<x<+\infty$, and $\mu_{F}(x)$ is a continuous mapping from $R$ to the closed interval $[0,1]$. A triangular fuzzy number denoted as $\widetilde{M}=(a, b, c)$ (Figure 1 ), where $a \leq b \leq c$, has the following triangular-type membership function [31]:

$$
\mu_{\widetilde{M}}(x)= \begin{cases}0, & x<a \\ \frac{x-a}{b-a}, & a \leq x \leq b \\ \frac{c-x}{c-b}, & b \leq x \leq c \\ 0, & x>c .\end{cases}
$$

Alternatively, by defining the interval of confidence level $\alpha$ (the so-called $\alpha$-cut), the triangular fuzzy number can be characterized as

$$
\begin{array}{r}
\forall \alpha \in[0,1] \\
\widetilde{M}_{\alpha}=\left[a^{\alpha}, c^{\alpha}\right]=[(b-a) \alpha+a,-(c-b) \alpha+c] .
\end{array}
$$


Some main operations for positive fuzzy numbers described by the interval of confidence are [32]

$$
\begin{array}{r}
\forall m_{L}, m_{R}, n_{L}, n_{R} \in R^{+}, \quad \widetilde{M}_{\alpha}=\left[m_{L}^{\alpha}, m_{R}^{\alpha}\right], \quad \widetilde{N}_{\alpha}=\left[n_{L}^{\alpha}, n_{R}^{\alpha}\right], \\
\alpha \in[0,1],
\end{array}
$$$$
\widetilde{M} \oplus \widetilde{N}=\left[m_{L}^{\alpha}+n_{L}^{\alpha}, m_{R}^{\alpha}+n_{R}^{\alpha}\right] \text { (addition rule), }
$$$$
\widetilde{M} \otimes \widetilde{N}=\left[m_{L}^{\alpha} n_{L}^{\alpha}, m_{R}^{\alpha} n_{R}^{\alpha}\right] \text { (multiplication rule) }
$$

The triangular fuzzy numbers, $\widetilde{1}$ to $\widetilde{9}$, are used to improve the traditional nine-point scaling scheme (i.e., 1 to 9). In order to take the vagueness of human qualitative assessments into consideration, the five triangular fuzzy numbers are defined with the corresponding membership functions.

3.3. Algorithm of Fuzzy AHP. In the fuzzy AHP, triangular fuzzy numbers are utilized to improve the scaling scheme in the judgment matrices and interval arithmetic is used to solve the fuzzy eigenvector [32]. The computational procedure of this methodology is summarized as follows [33].

Step 1. Just like the conventional AHP, the first step is to formulate a hierarchy system by decomposing the problem into a hierarchy of interrelated elements.

Step 2. Comparing the performance score, triangular fuzzy numbers $(\widetilde{1}, \widetilde{3}, \widetilde{5}, \widetilde{7}, \widetilde{9})$ are used to indicate the relative strength of each pair of elements in the same hierarchy.

Step 3. Constructing the fuzzy comparison matrix. By using triangular fuzzy numbers, via pairwise comparison, the fuzzy judgment matrix $\widetilde{A}\left(a_{i j}\right)$ is constructed as follows:

$$
\widetilde{A}=\left[\begin{array}{ccccc}
1 & \tilde{a}_{12} & \ldots & \tilde{a}_{1(n-1)} & \tilde{a}_{1 n} \\
\tilde{a}_{21} & 1 & \cdots & \tilde{a}_{2(n-1)} & \tilde{a}_{2 n} \\
\vdots & \vdots & \vdots & \vdots & \vdots \\
\tilde{a}_{(n-1) 1} & \tilde{a}_{(n-1) 2} & \cdots & 1 & \tilde{a}_{(n-1) n} \\
\tilde{a}_{n 1} & \widetilde{a}_{n 2} & \cdots & \tilde{a}_{n(n-1)} & 1
\end{array}\right]
$$

where

$$
\widetilde{a}_{i j}= \begin{cases}1, & i=j \\ \widetilde{1}, \widetilde{3}, \widetilde{5}, \widetilde{7}, \widetilde{9} \text { or } \tilde{1}^{-1}, \widetilde{3}^{-1}, \widetilde{5}^{-1}, \widetilde{7}^{-1}, \widetilde{9}^{-1}, & i \neq j\end{cases}
$$

Step 4. Solving fuzzy eigenvalues. A fuzzy eigenvalue, $\tilde{\lambda}$, is a fuzzy number solution to

$$
\widetilde{A} \tilde{x}=\tilde{\lambda} \tilde{x}
$$

where $\widetilde{A}$ is a $n \times n$ fuzzy matrix containing fuzzy numbers $\widetilde{a}_{i j}$ and $\tilde{x}$ is a nonzero $n \times 1$ fuzzy vector containing fuzzy umbers $\tilde{x}_{i}$.

To perform fuzzy multiplications and additions using the interval arithmetic and $\alpha$-cut, (6) is equivalent to

$$
\left[a_{i 1 l}^{\alpha} x_{1 l}^{\alpha}, a_{i 1 u}^{\alpha} x_{1 u}^{\alpha}\right] \oplus \cdots \oplus\left[a_{i n l}^{\alpha} x_{n l}^{\alpha}, a_{i n u}^{\alpha} x_{n u}^{\alpha}\right]=\left[\lambda x_{i l}^{\alpha}, \lambda x_{i u}^{\alpha}\right],
$$

where

$$
\begin{gathered}
\widetilde{A}=\left[\tilde{a}_{i j}\right], \quad \tilde{x}^{t}=\left(\tilde{x}_{1}, \ldots, \tilde{x}_{n}\right), \quad \widetilde{a}_{i j}^{\alpha}=\left[\widetilde{a}_{i j l}^{\alpha}, \widetilde{a}_{i j u}^{\alpha}\right], \\
\tilde{x}_{i}^{\alpha}=\left[\tilde{x}_{i l}^{\alpha}, \tilde{x}_{i u}^{\alpha}\right], \quad \tilde{\lambda}^{\alpha}=\left[\lambda_{l}^{\alpha}, \lambda_{u}^{\alpha}\right]
\end{gathered}
$$

for $0<\alpha \leq 1$ and all $i, j$, where $i=1,2, \ldots, n, j=1,2, \ldots, n$.

Step 5. Defuzzify fuzzy weight by importing pessimistic index [34]. Degree of satisfaction for the judgment matrix $\widetilde{A}$ is estimated by the pessimistic index $\mu$. The smaller value of the index $\mu$ indicates the higher degree of optimism. The index of pessimism is a linear convex combination defined as

$$
\widetilde{a}_{i j}^{\alpha}=\mu \widetilde{a}_{i j l}^{\alpha}+(1-\mu) \widetilde{a}_{i j u}^{\alpha}, \quad \forall \mu \in[0,1] .
$$

While $\alpha$-cut is fixed, the following matrix can be obtained after setting the pessimistic index $\mu$, in order to estimate the degree of satisfaction:

$$
\widetilde{A}=\left[\begin{array}{cccc}
1 & \widetilde{a}_{12}^{\alpha} & \cdots & \widetilde{a}_{1 n}^{\alpha} \\
\widetilde{a}_{21}^{\alpha} & 1 & \cdots & \widetilde{a}_{2 n}^{\alpha} \\
\vdots & \vdots & \ddots & \vdots \\
\widetilde{a}_{n 1}^{\alpha} & \widetilde{a}_{n 2}^{\alpha} & \cdots & 1
\end{array}\right] .
$$

The eigenvector is calculated by fixing the $\mu$ value and identifying the maximal eigenvalue.

Step 6. Determining the total weights. By synthesizing the priorities over all levels, the overall importance weights of green port factors are obtained by varying $\alpha$-cut value.

\section{Empirical Case Study}

Applying the AHP technique, this study adopts a two-stage methodology. In the first stage, AHP model is used to investigate the relative importance of green port factors; the second stage further utilizes those green port factors to evaluate the green port operational performance on three alternatives (i.e., the ports of Kaohsiung, Taichung, and Keelung in Taiwan). In particular, hoping to accurately represent port experts' ideas, fuzzy AHP algorithm is used to conduct the assessment of green ports' operation. Using AHP technique and twostage design to carry out evaluation and selection of certain activities or services has been a normal approach [35].

4.1. Data Collection. To obtain the comparative weight among the attribute of the decision elements, an AHP questionnaire was designed to collect data. Totally, 26 experts in Taiwan were invited to assess the comparative importance of green port factors and to estimate the green port performance on the top three ports in Taiwan in June 2013. Most of these 26 experts are senior employees with more than 20 years' experience working in research institute, maritime authorities, or port companies (Table 1). Relatively speaking, Taiwan has well-developed shipping and port industries. In liner shipping, the three biggest container carriers based in Taipei are Evergreen Marine Corporation, Yang Ming Marine Transport Corporation, and Wan Hai Line. There 
TABle 1: Profile of expert respondents.

\begin{tabular}{lccc}
\hline \multicolumn{1}{c}{ Profile of expert respondents } & No. & $\%$ \\
\hline \multirow{2}{*}{$\begin{array}{l}\text { Type of } \\
\text { organization }\end{array}$} & Port company & 13 & 50.0 \\
& Maritime authorities & 8 & 30.7 \\
& Research institute & 5 & 19.3 \\
& Total & $\mathbf{2 6}$ & $\mathbf{1 0 0 . 0}$ \\
\hline \multirow{2}{*}{ Job title } & Senior chief & 4 & 15.4 \\
& Junior chief & 10 & 38.4 \\
& Teaching and research & 5 & 19.3 \\
Working & Others & 7 & 26.9 \\
experience in the & $<5$ years & 3 & 11.5 \\
organization & 5-10 years & 3 & 11.5 \\
& 11-20 years & 6 & 23.1 \\
& $>20$ years & 14 & 53.9 \\
\hline
\end{tabular}

Sources: compiled for this research.

are also many bulk carriers providing tramp services. The total ships controlled by the Taiwanese were more than 39.1 million deadweight tons (DWT) in 2012, accounting for 2.81 percent of the total world ship's tonnage; although over $89.56 \%$ are the so-called flag-of-convenience (FOC) ships [1]. In the meantime, port of Kaohsiung was ranked as the top 13th container port worldwide in 2012 with throughput of 9.78 million TEUs containers [36]. Owing to the strong background of shipping and port industries in Taiwan, the surveyed data is considered as appropriate to shed some light on green port operational practice.

4.2. The Importance of Green Port Factors with AHP Method. The first step of AHP model is to set up a hierarchy system, which is composed of several hierarchies and includes goal, criteria of various types of influence, subcriteria, and decision alternatives to determine the best choice. Subcriteria under a criterion must be homogeneous before they can be mutually compared [37]. Criteria in the same hierarchy must be mutually independent. For this study, based on the green port literatures reviewed in Section 2, a green port AHP model is formulated and shown in Figure 2. It includes five dimensions (i.e., major criteria) and 13 subcriteria, which will be used to estimate whether a port achieves a green operation status.

The five dimensions of green port operation are categorized based on reviewing many port authorities' green port measures and earlier studies, such as Darbra et al. [8], PerisMora et al. [9], Bailey and Solomon [20], Klopott [21], and Chiu and Lai [24]. Regarding those 13 subcriteria, Table 2 provides more detailed information about what kind of actions the port authorities should do to enhance its greener condition. In addition, the previous study has confirmed that those 13 factors are highly relevant to green port operation. As shown in Table 3, the mean value of importance are all higher than 3.5 under the 5-point scaling system. Consequently, the green port hierarchy system of this study is considered appropriately.
TABLE 2: Types of green port measures and actions.

\begin{tabular}{|c|c|}
\hline Measures & Detailed actions \\
\hline \multirow{21}{*}{$\begin{array}{l}\text { Air pollution } \\
\text { (AP) }\end{array}$} & AP1. Set up air quality monitoring system \\
\hline & $\begin{array}{l}\text { AP2. Set up sulfur and nitrogen emissions } \\
\text { control area }\end{array}$ \\
\hline & AP3. Provide shore power \\
\hline & AP4. Use energy from renewable sources \\
\hline & AP5. Use more electric machines/equipments \\
\hline & AP6. Use automated gateway system \\
\hline & AP7. Install air filter on port machines \\
\hline & $\begin{array}{l}\text { AP8. Port machines use clean fuel with lower } \\
\text { sulfur content }\end{array}$ \\
\hline & AP9. Monitor dust levels \\
\hline & $\begin{array}{l}\text { AP10. Implement dust and smoke recycle } \\
\text { measures }\end{array}$ \\
\hline & AP11. Monitor smoke from vessels \\
\hline & $\begin{array}{l}\text { AP12. Adjust the type of importing bulk cargo } \\
\text { (e.g., replace coal splinter with block coal) }\end{array}$ \\
\hline & $\begin{array}{l}\text { AP13. Promote environment-friendly } \\
\text { transport }\end{array}$ \\
\hline & $\begin{array}{l}\text { A14. Promote port ride share or use shuttle } \\
\text { bus }\end{array}$ \\
\hline & AP15. Establish the carbon footprint \\
\hline & AP16. Vessel speed reduction in port \\
\hline & $\begin{array}{l}\text { AP17. Idle control on vehicles and cargo } \\
\text { handling equipments }\end{array}$ \\
\hline & AP18. Idle truck parking arrangement \\
\hline & AP19. Use lower air pollution truck \\
\hline & AP20. Replace or improve the old vehicles \\
\hline & $\begin{array}{l}\text { AP21. Vehicles and vessels to use clean fuel } \\
\text { with lower sulfur content }\end{array}$ \\
\hline \multirow{7}{*}{$\begin{array}{l}\text { Water } \\
\text { pollution } \\
\text { (WP) }\end{array}$} & WP1. Dredge monitoring and assessment \\
\hline & WP2. Investigate sewage source \\
\hline & $\begin{array}{l}\text { WP3. Monitor water quality } \\
\text { WP4. Handle spill oil emergency }\end{array}$ \\
\hline & WP5. Install palisade on sewage pipe \\
\hline & WP6. Manage ballast water \\
\hline & WP7. Handle on board sewage \\
\hline & $\begin{array}{l}\text { WP8. Improve the standard of ship's } \\
\text { sanitation equipment }\end{array}$ \\
\hline \multirow{5}{*}{$\begin{array}{l}\text { Noise } \\
\text { pollution } \\
(\mathrm{NP})\end{array}$} & NP1. Set high standards of noise limits \\
\hline & $\begin{array}{l}\text { NP2. Monitor noise levels during } \\
\text { construction and operation }\end{array}$ \\
\hline & NP3. Require to use lower noise \\
\hline & $\begin{array}{l}\text { NP4. Install double insulation windows and } \\
\text { boards }\end{array}$ \\
\hline & $\begin{array}{l}\text { NP5. Use noise reduction machines (forklifts, } \\
\text { ships, trucks, and other devices vehicles) }\end{array}$ \\
\hline \multirow{3}{*}{$\begin{array}{l}\text { Land and } \\
\text { sediments } \\
\text { pollution } \\
\text { (LP) }\end{array}$} & LP1. Remediation of contaminated sites \\
\hline & LP2. Reuse of dredge sediments \\
\hline & $\begin{array}{l}\text { LP3. Sediments deposited in the separated } \\
\text { area }\end{array}$ \\
\hline
\end{tabular}


TABLe 2: Continued.

\begin{tabular}{|c|c|}
\hline Measures & Detailed actions \\
\hline \multirow{5}{*}{$\begin{array}{l}\text { Materials } \\
\text { selection } \\
(\mathrm{MS})\end{array}$} & MS1. Adopt LEED standard for green building \\
\hline & $\begin{array}{l}\text { MS2. Procure locally available materials and } \\
\text { suppliers }\end{array}$ \\
\hline & $\begin{array}{l}\text { MS3. Use reusable materials for } \\
\text { building/facility }\end{array}$ \\
\hline & $\begin{array}{l}\text { MS4. Encourage using environment-friendly } \\
\text { materials }\end{array}$ \\
\hline & $\begin{array}{l}\text { MS5. Port landscaping to use local native } \\
\text { species }\end{array}$ \\
\hline \multirow{3}{*}{$\begin{array}{l}\text { Water } \\
\text { consumption } \\
\text { (WS) }\end{array}$} & $\begin{array}{l}\text { WS1. Reduce waste of drinking water and } \\
\text { irrigation }\end{array}$ \\
\hline & WS2. Monitor water usage and leakage \\
\hline & WS3. On-site water treatment and reuse \\
\hline \multirow{6}{*}{$\begin{array}{l}\text { Energy usage } \\
(\mathrm{EU})\end{array}$} & $\begin{array}{l}\text { EU1. Use new environment-friendly energy in } \\
\text { office and port area (e.g., solar power) }\end{array}$ \\
\hline & EU2. Microclimate design \\
\hline & EU3. Use energy efficient control system \\
\hline & $\begin{array}{l}\text { EU4. Use "heat stop" paint to coat the } \\
\text { refrigerated containers }\end{array}$ \\
\hline & EU5. E-document program \\
\hline & EU6. Use energy efficient light in port area \\
\hline \multirow{6}{*}{$\begin{array}{l}\text { General } \\
\text { waste } \\
\text { handling } \\
(\mathrm{GH})\end{array}$} & GH1. Recycle publications or office waste \\
\hline & $\begin{array}{l}\text { GH2. Reduce packaging use and choice fewer } \\
\text { packaging use supplier }\end{array}$ \\
\hline & $\begin{array}{l}\text { GH3. Provide a dedicated storage area for } \\
\text { recycling }\end{array}$ \\
\hline & GH4. Reuse the construction waste materials \\
\hline & GH5. Garbage classification in port area \\
\hline & GH6. Vessel waste classification \\
\hline \multirow{3}{*}{$\begin{array}{l}\text { Hazardous } \\
\text { waste } \\
\text { handling } \\
(\mathrm{HH})\end{array}$} & $\begin{array}{l}\text { HH1. Separate hazardous goods and poisons } \\
\text { during construction and operation }\end{array}$ \\
\hline & $\begin{array}{l}\mathrm{HH} 2 \text {. Employ licensed contractor to handle } \\
\text { hazardous waste }\end{array}$ \\
\hline & $\begin{array}{l}\text { HH3. Sterilizing and burning of cargoes } \\
\text { coming from epidemic area }\end{array}$ \\
\hline \multirow{4}{*}{$\begin{array}{l}\text { Habitat } \\
\text { quality (HQ) }\end{array}$} & HQ1. Establish indicators of habitat quality \\
\hline & HQ2. Ecological monitoring in port area \\
\hline & $\begin{array}{l}\text { HQ3. Establish compensation area or } \\
\text { alternative area }\end{array}$ \\
\hline & $\begin{array}{l}\text { HQ4. Expansion of tidal areas for habitat } \\
\text { restoration }\end{array}$ \\
\hline \multirow{3}{*}{$\begin{array}{l}\text { Port greenery } \\
(\mathrm{PG})\end{array}$} & PG1. grow flowers or trees in port area \\
\hline & PG2. Use biological spectrum lighting \\
\hline & $\begin{array}{l}\text { PG3. Use nonchemical composition of } \\
\text { pesticide and fertilizer }\end{array}$ \\
\hline \multirow{6}{*}{$\begin{array}{l}\text { Community } \\
\text { promotion } \\
\text { and } \\
\text { education } \\
\text { (CE) }\end{array}$} & CE1. Allow public to have port tour \\
\hline & CE2. Provide job opportunity \\
\hline & $\begin{array}{l}\text { CE3. Encourage public participating in port } \\
\text { planning }\end{array}$ \\
\hline & CE4. Provide green port web site \\
\hline & $\begin{array}{l}\text { CE5. Promote green port concept for the } \\
\text { community }\end{array}$ \\
\hline & CE6. Public opinion survey \\
\hline
\end{tabular}

TABLE 2: Continued.

\begin{tabular}{ll}
\hline Measures & Detailed actions \\
\hline & PT1. Hold green port seminar \\
Port staff & PT2. Provide green facilities/building guide \\
training (PT) & and training \\
& PT3. Implement an accredited Environmental \\
& Management System \\
& PT4. Provide green port training \\
\hline
\end{tabular}

Sources: adapted from Chiu and Lai [24].

TABLE 3: Relevant factors of green port operation.

\begin{tabular}{llcc}
\hline Rank & Green port measures & Mean $^{*}$ & S.D. \\
\hline 1 & Hazardous waste handling & 4.44 & 0.051 \\
2 & Water pollution & 4.21 & 0.121 \\
3 & Air pollution & 4.01 & 0.1921 \\
4 & General waste handling & 3.95 & 0.172 \\
5 & Water consumption & 3.93 & 0.072 \\
6 & Energy usage & 3.89 & 0.198 \\
7 & Materials selection & 3.87 & 0.039 \\
8 & Noise pollution & 3.82 & 0.063 \\
9 & Land and sediments pollution & 3.81 & 0.056 \\
10 & Habitat quality maintenance & 3.67 & 0.152 \\
11 & Port greenery & 3.66 & 0.132 \\
12 & Port staff training & 3.63 & 0.088 \\
13 & Community promotion and education & 3.50 & 0.165 \\
\hline
\end{tabular}

${ }^{*}$ All developed using 5-point Likert scale, where 5: extremely important; 1 : extremely unimportant.

Sources: adapted from Chiu and Lai [24].

4.2.1. Priorities of Green Port Factors. The priorities of criteria and subcriteria for achieving a green port operation are shown in Table 4. In that Table, the evaluating criterion having the most profound effect on the goal of constructing and operating a "greener" port is assigned to improve environmental quality, and the priority weight is calculated to be 0.322 . Then, the use of energy and resource and habitat quality and greenery obtained priority weights of 0.214 and 0.184 , respectively. The other two factors waste handling and social participation obtained priority weights of 0.164 and 0.118 , respectively.

The priority order of subcriteria is hazardous waste handling (0.124), air pollution (0.110), water pollution (0.104), port greenery (0.102), habitat quality maintenance $(0.080)$, energy usage (0.077), water consumption (0.074), port staff training (0.065), materials selection (0.061), land and sediments pollution (0.059), community promotion and education (0.053), and noise pollution (0.052), as well as general waste handling $(0.039)$. The total weight of the top five criteria accounted for $52.0 \%$ of all (Table 5).

4.3. Performance Evaluation of Alternatives with Fuzzy AHP Technique. In order to acquire more detailed information, the AHP model usually employs lower level attributes to assess the performance of alternatives $[35,38]$. Following the practice and applying the fuzzy AHP technique mentioned previously, this study invites 26 experts to use the 13 factors 
Level 1

Goal

Level 2

Major criteria

Level 3

Subcriteria

Level 4

Alternatives

Evaluation

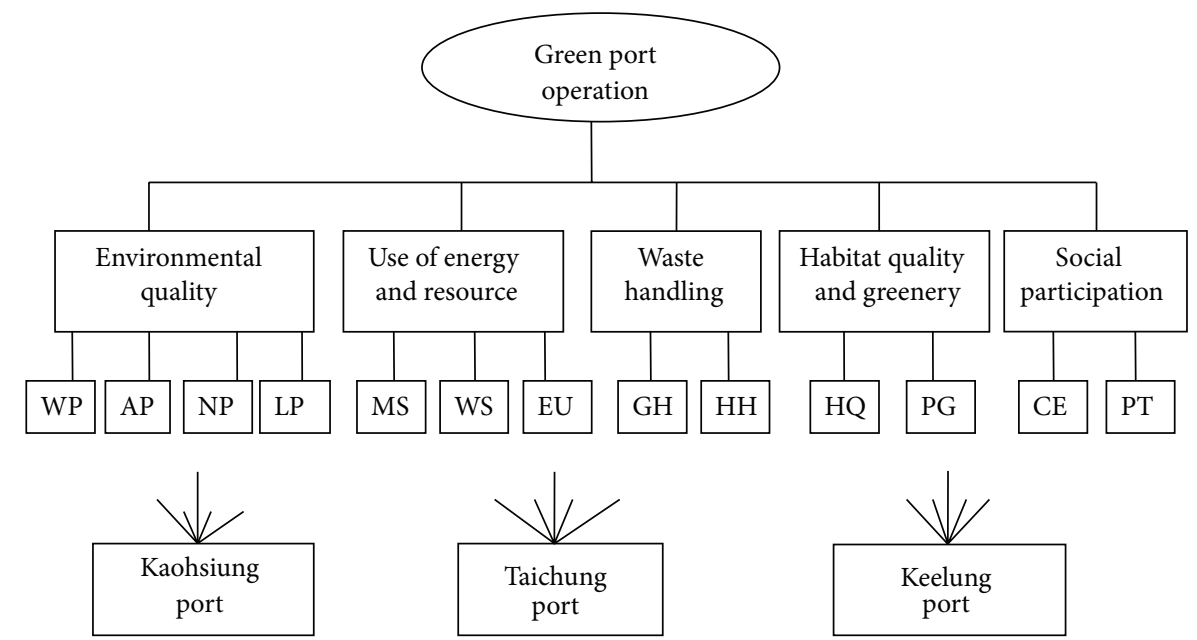

WP: water pollution

AP: air pollution

GH: general waste handling

$\mathrm{HH}$ : hazardous waste handling

NP: noise pollution

HQ: habitat quality maintenance

LP: land and sediments pollution

PG: port greenery

MS: materials selection

CE: community promotion and education

WS: water consumption

PT: port staff training

EU: energy usage

FIGURE 2: An AHP model for green port assessment.

TABLE 4: Composite priority weights for major criteria and subcriteria.

\begin{tabular}{|c|c|c|c|c|}
\hline Criteria & Local weights & Subcriteria & Local weights & Global weights \\
\hline \multirow{4}{*}{ Environmental quality } & \multirow{4}{*}{0.322} & Water pollution & 0.346 & 0.104 \\
\hline & & Air pollution & 0.327 & 0.110 \\
\hline & & Land and sediments pollution & 0.182 & 0.059 \\
\hline & & Noise pollution & 0.162 & 0.052 \\
\hline \multirow{3}{*}{ Use of energy and resource } & \multirow{3}{*}{0.214} & Energy usage & 0.361 & 0.077 \\
\hline & & Materials selection & 0.351 & 0.061 \\
\hline & & Water consumption & 0.288 & 0.074 \\
\hline \multirow{2}{*}{ Habitat quality and greenery } & \multirow{2}{*}{0.184} & Port greenery & 0.562 & 0.102 \\
\hline & & Habitat quality maintenance & 0.438 & 0.080 \\
\hline \multirow{2}{*}{ Waste handling } & \multirow{2}{*}{0.164} & Hazardous waste handling & 0.762 & 0.124 \\
\hline & & General waste handling & 0.238 & 0.039 \\
\hline \multirow{3}{*}{ Social participation } & \multirow{3}{*}{0.118} & Port staff training & 0.549 & 0.065 \\
\hline & & Community promotion and education & 0.451 & 0.053 \\
\hline & & & Total & 1.000 \\
\hline
\end{tabular}

(subcriterion) to evaluate the green port performance of the three largest ports in Taiwan.

For easier application of the fuzzy AHP technique to evaluate green port performance, the operational procedures are proposed to get the results. Regarding this empirical case, there are $m$ experts by using $n$ criteria $C_{j}(j=1,2,3, \ldots, n)$ to $k$ ports' performance $\left(A_{t},(t=1,2,3, \ldots, k)\right)$ on greener operations. The operational procedures are as the following.

Step 1. Expert $D_{i}$ follows fuzzy linguistic rule (Table 6) [39, 40 ] to evaluate $A_{t}$ port's green performance on $n$ subcriterion $C_{j}$ and the evaluation result as $\widetilde{P}_{i j}^{i}=\left(l_{i j}^{i}, m_{i j}^{i}, u_{i j}^{i}\right)$.
Step 2. Integrating $m$ experts' evaluation, we obtain the aggregate fuzzy rating of subcriteria $C_{j}$ for each port $A_{t}$ as

$$
\widetilde{P}_{i j}=\left(l_{i j}, m_{i j}, u_{i j}\right) \text {, }
$$

where

$$
\begin{gathered}
l_{i j}=\min \left\{l_{i j}^{i}\right\}, \quad i=1, \ldots, m, \\
m_{i j}=\left(\prod_{i=1}^{m} m_{i j}^{i}\right)^{1 / m}, \quad i=1, \ldots, m . \\
u_{i j}=\max \left\{u_{i j}^{i}\right\}, \quad i=1, \ldots, m,
\end{gathered}
$$


TABLe 5: Priority order of subcriteria.

\begin{tabular}{lcc}
\hline Rank & Critical success factors (subcriteria) & Global weights \\
\hline 1 & Hazardous waste handling & 0.124 \\
2 & Air pollution & 0.110 \\
3 & Water pollution & 0.104 \\
4 & Port greenery & 0.102 \\
5 & Habitat quality maintenance & 0.080 \\
6 & Energy usage & 0.077 \\
7 & Water consumption & 0.074 \\
8 & Port staff training & 0.065 \\
9 & Materials selection & 0.061 \\
10 & Land and sediments pollution & 0.059 \\
11 & Community promotion and education & 0.053 \\
12 & Noise pollution & 0.052 \\
13 & General waste handling & 0.039 \\
\hline
\end{tabular}

TABle 6: Fuzzy linguistic assessment variables.

\begin{tabular}{lcc}
\hline $\begin{array}{l}\text { Fuzzy } \\
\text { number }\end{array}$ & $\begin{array}{c}\text { Verbal judgment or } \\
\text { preference }\end{array}$ & $\begin{array}{c}\text { Triangle fuzzy } \\
\text { numbers }\end{array}$ \\
\hline$\widetilde{1}$ & Very poor & $(1,1,3)$ \\
$\widetilde{3}$ & Poor & $(1,3,5)$ \\
$\widetilde{5}$ & Normal & $(3,5,7)$ \\
$\widetilde{7}$ & Good & $(5,7,9)$ \\
$\widetilde{9}$ & Very good & $(7,9,9)$ \\
\hline
\end{tabular}

Step 3. Obtain the total fuzzy rating $\left(\widetilde{P}_{t}\right)$ for each port $A_{t},(t=$ $1,2,3, \ldots, k)$ as

$$
\widetilde{P}_{t}=\frac{1}{n} \otimes\left\{\left(\widetilde{P}_{t 1} \otimes W_{1}\right) \oplus\left(\widetilde{P}_{t 2} \otimes W_{2}\right) \oplus \cdots \oplus\left(\widetilde{P}_{t n} \otimes W_{n}\right)\right\} .
$$

Step 4. Applying the $\alpha$-cut $(0 \leqq \alpha \leqq 1)$ method, we get the lower bound $\left(P_{t l}^{\alpha}\right)$ and upper bound $\left(P_{t u}^{\alpha}\right)$ of $\widetilde{P}_{t}$ as

$$
P_{t}^{\alpha}=\left[P_{t l}^{\alpha}, P_{t u}^{\alpha}\right] \text {. }
$$

Considering the decision maker's attitude towards decisionmaking, the pessimistic index [34] $\mu(0 \leqq \mu \leqq 1)$ is used to calculate the final fuzzy rating as

$$
P_{t \lambda}^{\alpha}=\mu \cdot P_{t l}^{\alpha}+(1-\mu) \cdot P_{t u}^{\alpha} .
$$

When $\mu=0$, which means the decision maker is an extreme optimist, then $\widetilde{P}_{t}$ is the upper bound of $\alpha$-cut $\left(P_{t u}^{\alpha}\right)$; conversely, when $\mu=1$, which means the decision maker is an extreme pessimist, then $\widetilde{P}_{t}$ is the lower bound of $\alpha$-cut $\left(P_{t l}^{\alpha}\right)$. By changing the $\mu$ value, we can test the influence of decision maker's preference on final results.

Step 5. Through importing the different combinations of $\alpha$ cut and $\mu$ value, we can get the changes of final fuzzy rating on each alternative. Then, the information will be provided for decision makers to make a final decision.

Table 7 shows the aggregate fuzzy rating on each subcriterion for the three alternatives (port of Kaohsiung, Taichung,

\begin{tabular}{|c|c|c|c|c|}
\hline $\begin{array}{l}\text { Green port } \\
\text { factors }\end{array}$ & Alternatives & $P_{l}$ & $P_{m}$ & $P_{u}$ \\
\hline \multirow{3}{*}{$\begin{array}{l}\text { Hazardous } \\
\text { waste handling }\end{array}$} & Kaohsiung & 0.125 & 0.708 & 1.125 \\
\hline & Taichung & 0.125 & 0.762 & 1.125 \\
\hline & Keelung & 0.125 & 0.762 & 1.125 \\
\hline \multirow{3}{*}{ Air pollution } & Kaohsiung & 0.111 & 0.471 & 0.999 \\
\hline & Taichung & 0.111 & 0.576 & 0.999 \\
\hline & Keelung & 0.111 & 0.580 & 0.999 \\
\hline \multirow{3}{*}{ Water pollution } & Kaohsiung & 0.105 & 0.480 & 0.945 \\
\hline & Taichung & 0.105 & 0.573 & 0.945 \\
\hline & Keelung & 0.105 & 0.497 & 0.945 \\
\hline \multirow{3}{*}{ Port greenery } & Kaohsiung & 0.103 & 0.593 & 0.927 \\
\hline & Taichung & 0.309 & 0.648 & 0.927 \\
\hline & Keelung & 0.103 & 0.590 & 0.927 \\
\hline \multirow{3}{*}{$\begin{array}{l}\text { Habitat quality } \\
\text { maintenance }\end{array}$} & Kaohsiung & 0.081 & 0.395 & 0.729 \\
\hline & Taichung & 0.081 & 0.444 & 0.729 \\
\hline & Keelung & 0.081 & 0.414 & 0.729 \\
\hline \multirow{3}{*}{ Energy usage } & Kaohsiung & 0.077 & 0.390 & 0.693 \\
\hline & Taichung & 0.077 & 0.432 & 0.693 \\
\hline & Keelung & 0.077 & 0.422 & 0.693 \\
\hline \multirow{3}{*}{$\begin{array}{l}\text { Water } \\
\text { consumption }\end{array}$} & Kaohsiung & 0.074 & 0.374 & 0.666 \\
\hline & Taichung & 0.074 & 0.358 & 0.666 \\
\hline & Keelung & 0.074 & 0.402 & 0.666 \\
\hline \multirow{3}{*}{$\begin{array}{l}\text { Port staff } \\
\text { training }\end{array}$} & Kaohsiung & 0.065 & 0.374 & 0.585 \\
\hline & Taichung & 0.065 & 0.370 & 0.585 \\
\hline & Keelung & 0.065 & 0.376 & 0.585 \\
\hline \multirow{3}{*}{$\begin{array}{l}\text { Materials } \\
\text { selection }\end{array}$} & Kaohsiung & 0.061 & 0.339 & 0.549 \\
\hline & Taichung & 0.061 & 0.332 & 0.549 \\
\hline & Keelung & 0.061 & 0.351 & 0.549 \\
\hline \multirow{3}{*}{$\begin{array}{l}\text { Land and } \\
\text { sediments } \\
\text { pollution }\end{array}$} & Kaohsiung & 0.059 & 0.281 & 0.531 \\
\hline & Taichung & 0.059 & 0.323 & 0.531 \\
\hline & Keelung & 0.059 & 0.288 & 0.531 \\
\hline \multirow{3}{*}{$\begin{array}{l}\text { Community } \\
\text { promotion and } \\
\text { education }\end{array}$} & Kaohsiung & 0.053 & 0.277 & 0.477 \\
\hline & Taichung & 0.053 & 0.277 & 0.477 \\
\hline & Keelung & 0.053 & 0.286 & 0.477 \\
\hline \multirow{3}{*}{ Noise pollution } & Kaohsiung & 0.052 & 0.260 & 0.468 \\
\hline & Taichung & 0.052 & 0.301 & 0.468 \\
\hline & Keelung & 0.052 & 0.228 & 0.468 \\
\hline \multirow{3}{*}{$\begin{array}{l}\text { General waste } \\
\text { handling }\end{array}$} & Kaohsiung & 0.039 & 0.232 & 0.351 \\
\hline & Taichung & 0.039 & 0.225 & 0.351 \\
\hline & Keelung & 0.117 & 0.242 & 0.351 \\
\hline \multirow{3}{*}{ Total rating } & Kaohsiung & 0.077 & 0.398 & 0.696 \\
\hline & Taichung & 0.093 & 0.432 & 0.696 \\
\hline & Keelung & 0.083 & 0.418 & 0.696 \\
\hline
\end{tabular}
and Keelung). For easier judging which port has achieved
TABLE 7: Summarizes of green performance of each alternative.

the better performance on green operation, Figure 3 presents the fuzzy utility of the three empirical cases. The results consistently indicate that under different levels of $\alpha$-cut the values of lower bound and upper bound of the three empirical 


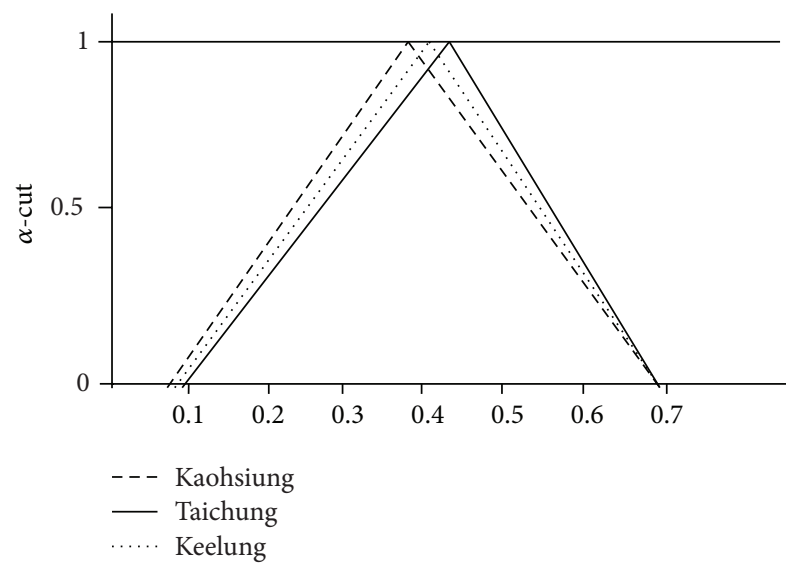

FIgure 3: Total fuzzy ratings of alternatives $\left(A_{t}\right)$.

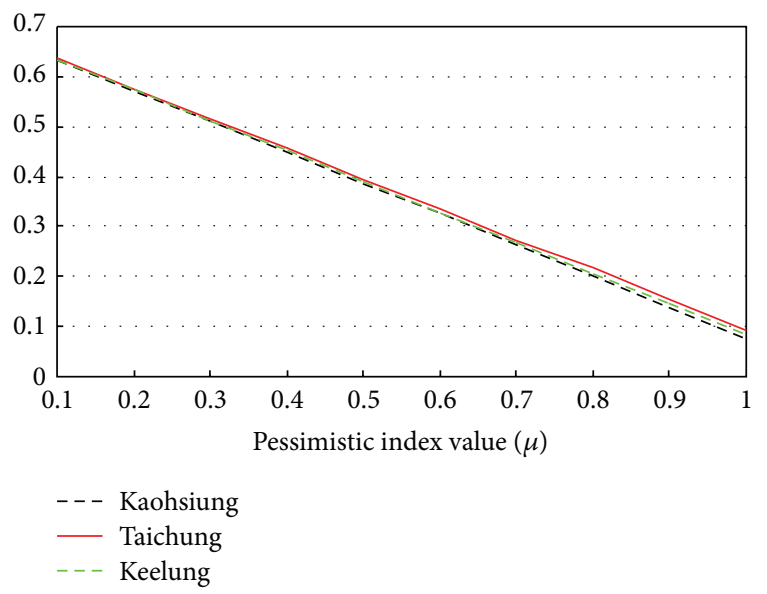

FIgURE 4: Sensitivity analysis when $\mu$ varies $(\alpha=0)$.

cases would be Taichung $>$ Keelung $>$ Kaohsiung. That means the outranking of green operation performance for individual port would be Taichung port is the best and then followed by Keelung; the third is Kaohsiung.

4.3.1. The Sensitivity Analysis. As indicated in Figure 3, under the condition of $\alpha=1$, the ratings of green port performance of port Taichung, Keelung, and Kaohsiung are $0.432,0.418$ and 0.398 , respectively; those results will not vary along with the changes of pessimistic index $(\mu)$. As mentioned in Section 3.2, theoretically the total fuzzy ratings of alternatives would be a fixed number under the condition of $\alpha=1$ in accordance with the algorithm of triangular-type membership function. However, by varying the values of $\alpha$-cut (to show the fuzziness) and decisionmaker's judgmental attitudes (the pessimistic index $\mu$ ), the performance of alternatives may be different. Accordingly, a sensitivity test is conducted to examine this issue.

The sensitivity test is conducting through different combinations of $\alpha$-cut and $\mu$ value; that is, by setting two conditions of $\alpha$-cut values ( $\alpha=0$ and 0.5 ) and varying $\mu$ value (between 0.1 and 1.0). The results are shown in Table 8 and

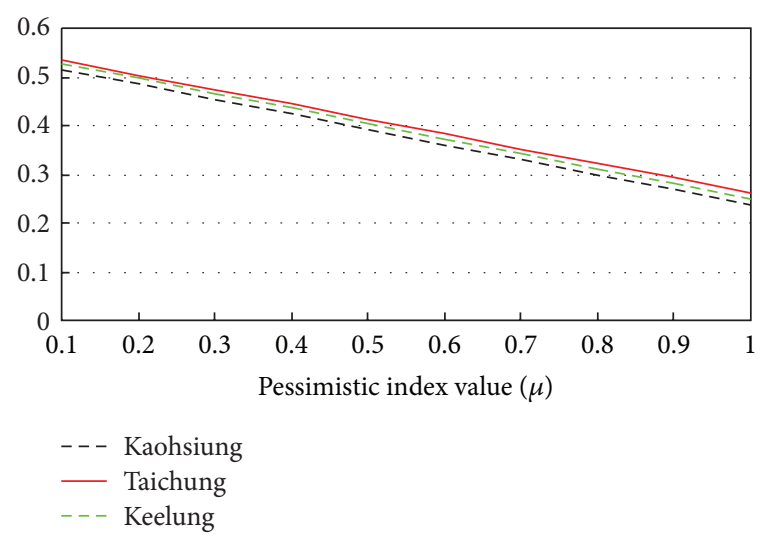

FIGURE 5: Sensitivity analysis when $\mu$ varies $(\alpha=0.5)$.

Figure 4 as well as Table 9 and Figure 5. Under the two fuzzy set conditions ( $\alpha=0$ and 0.5 ), the results consistently show that the order of performance ratings is port of Taichung is higher than Keelung and Kaohsiung, and again Keelung is higher than Kaohsiung. Practically, these results point out that all experts consider that the order of green port performance is Taichung port is the best and then followed by Keelung; and the third is Kaohsiung port.

\section{Conclusions}

The major contributions of this paper are (a) to identify the factors of green ports obtain from reviewing the previous academic studies and many port authorities' practical actions, (b) to construct an AHP model for pointing out the priority of green port factors, which can provide for port industry a guidance for constructing and operating a greener port, and (c) to propose a fuzzy-AHP algorithm for evaluating green port performance. As the OECD report points out that growing concerns about the environmental unsustainability of past economic growth patterns and increased awareness of a potential future climate crisis have made it clear that the environment and the economy can no longer be considered in isolation [41], therefore, green growth is advocated as a way to pursue economic growth and development, while preventing environmental degradation, biodiversity loss, and unsustainable natural resource use. In the international transport logistics chain, green concept is also introduced into port development and operation. The main conclusions of this research are as follows.

(1) After reviewing many studies on port operation with relation to environmental protection and green issue, most of the researches are seemingly focused on pollution sources. In addition, many port authorities propose green guidelines and require users (such as calling ships) to follow their green operational measures to reduce pollution. However, there seems no comprehensive model to be formulated for evaluating the green performance of a port. Founded on the previous literatures, the current study proposed an 
Table 8: Performance sensitivity when pessimistic index $(\mu)$ varies $(\alpha=0)$.

\begin{tabular}{lcccccccccc}
\hline$\mu$ & 0.1 & 0.2 & 0.3 & 0.4 & 0.5 & 0.6 & 0.7 & 0.8 & 0.9 & 1.0 \\
\hline Kaohsiung & 0.634 & 0.572 & 0.510 & 0.448 & 0.387 & 0.325 & 0.263 & 0.201 & 0.139 & 0.077 \\
Taichung & 0.636 & 0.575 & 0.515 & 0.455 & 0.394 & 0.334 & 0.274 & 0.219 & 0.153 & 0.093 \\
Keelung & 0.635 & 0.573 & 0.512 & 0.451 & 0.390 & 0.328 & 0.267 & 0.206 & 0.145 & 0.083 \\
\hline
\end{tabular}

TABLE 9: Performance sensitivity when pessimistic index $(\mu)$ varies $(\alpha=0.5)$.

\begin{tabular}{lcccccccccc}
\hline$\mu$ & 0.1 & 0.2 & 0.3 & 0.4 & 0.5 & 0.6 & 0.7 & 0.8 & 0.9 & 1.0 \\
\hline Kaohsiung & 0.516 & 0.485 & 0.454 & 0.423 & 0.392 & 0.361 & 0.331 & 0.300 & 0.269 & 0.238 \\
Taichung & 0.534 & 0.504 & 0.474 & 0.444 & 0.413 & 0.383 & 0.353 & 0.323 & 0.293 & 0.263 \\
Keelung & 0.526 & 0.496 & 0.465 & 0.435 & 0.404 & 0.373 & 0.343 & 0.312 & 0.281 & 0.251 \\
\hline
\end{tabular}

FAHP model for evaluating the green port operation (Figure 2).

(2) Through an empirical case study by inviting 26 experts in Taiwan to provide their professional judgment, the importance ranking of the five major criteria and 13 subcriteria has been pinpointed. The results (in Tables 4 and 5) would be a good referral for decision makers of port organizations to prioritize and choose their actions and efforts for forging a "greener" port operation.

(3) The green port FAHP model also can be used to evaluate the port's green operation performance. This study provides an easier operational procedure to get the results. For the empirical case by applying FAHP algorithm, this study concludes that currently the green port performance of the top three ports in Taiwan is port of Taichung is ranked the first, which is followed by Keelung, and the third is Kaohsiung. Under the limit of resources, it would be difficult for ports to fully implement all greener requirements for constructing facilities and operational activities. The more feasible action is to choose the more important factors as the priority implementation items. AHP or FAHP technique provides a good solution for helping decision makers to take appropriate actions.

Based on the results of this study, some future research directions are suggested. First, although Taichung port is currently evaluated as a better port with higher green port performance ratings, a further qualitative study is needed to explore the more detailed advantage aspects with the port. Secondly, in view of the necessity of operating a port in a greener way in the future, a cost-benefit research is required to find out some feasible solutions for operating a greener port without heavy financial burden.

\section{Conflict of Interests}

The authors declare that there is no conflict of interests regarding the publication of this paper.

\section{Acknowledgments}

The authors acknowledge the funding from the National Science Council, R.O.C. (Grant no. NSC-101-2410-H-019005).

\section{References}

[1] United Nations Conference on Trade and Development (UNCTAD), Review of Maritime Transport 2012, United Nations, Geneva, Switzerland, 2012.

[2] M. Gavrilescu and Y. Chisti, "Biotechnology: a sustainable alternative for chemical industry," Biotechnology Advances, vol. 23, no. 7-8, pp. 471-499, 2005.

[3] G. Brundtland, Our Common Future, Oxford University Press, Oxford, UK, 1987.

[4] B. Dalal-Clayton and S. Bass, Sustainable Development Strategies: A Resource Book, Earthscan, London, UK, 2002.

[5] H. Komiyama and S. Kraines, Vision 2050: Roadmap for a Sustainable Earth, Springer, New York, NY, USA, 2008.

[6] C. Vezzoli and E. Manzini, Design and Innovation for Sustainability, Springer, London, UK, 2008.

[7] M. Luo and T. L. Yip, "Ports and the environment," Maritime Policy and Management, vol. 40, no. 5, pp. 401-403, 2013.

[8] R. M. Darbra, A. Ronza, T. A. Stojanovic, C. Wooldridge, and J. Casal, "A procedure for identifying significant environmental aspects in sea ports," Marine Pollution Bulletin, vol. 50, no. 8, pp. 866-874, 2005.

[9] E. Peris-Mora, J. M. D. Orejas, A. Subirats, S. Ibáñez, and P. Alvarez, "Development of a system of indicators for sustainable port management," Marine Pollution Bulletin, vol. 50, no. 12, pp. 1649-1660, 2005.

[10] A. Ashar, "The fourth revolution," in Containerisation International, pp. 57-61, 1999.

[11] United Nations Conference on Trade and Development (UNCTAD), Maritime Transport and the Climate Change Challenge: Summary of Proceedings, United Nations, Geneva, Switzerland, (UNCTAD/DTL/TLB/2009/1), 2009.

[12] H. N. Psaraftis and C. A. Kontovas, "Balancing the economic and environmental performance of maritime transportation," Transportation Research D, vol. 15, no. 8, pp. 458-462, 2010.

[13] M. S. Eide, Ø. Endresen, R. Skjong, T. Longva, and S. Alvik, "Cost-effectiveness assessment of $\mathrm{CO}_{2}$ reducing measures in shipping," Maritime Policy and Management, vol. 36, no. 4, pp. 367-384, 2009. 
[14] H. Johnson, M. Johansson, K. Andersson, and B. Sodahl, "Will the ship energy efficiency management plan reduce $\mathrm{CO}_{2}$ emissions? A comparison with ISO, 50001 and the ISM code," Maritime Policy and Management, vol. 40, no. 2, pp. 177-190, 2013.

[15] C. Kontovas and A. H. N. Psaraftis, "Reduction of emissions along the maritime inter modal container chain: operational models and policies," Maritime Policy and Management, vol. 38, no. 4, pp. 451-469, 2011.

[16] J. K. Woo and D. S. H. Moon, "The effects of slow steaming on the environmental performance in liner shipping," in Maritime Policy and Management, pp. 1-16, 2013.

[17] M. Tull, "The environmental impact of ports: an Australian case study," in Proceedings of the 14th International Economic History Congress, Helsinki, Finland, August 2006.

[18] N. A. Braathen, Ed., Environmental Impacts of International Shipping: the Role of Ports, OECD Publishing, Paris, France, 2011.

[19] OECD, Environmental Impacts of International Shipping: A Case Study of the Port of Vancouver, OECD Publishing, Paris, France, 2009.

[20] D. Bailey and G. Solomon, "Pollution prevention at ports: clearing the air," Environmental Impact Assessment Review, vol. 24, no. 7-8, pp. 749-774, 2004.

[21] M. Klopott, "Restructuring of environmental management in Baltic ports: case of Poland," Maritime Policy and Management, vol. 40, no. 5, pp. 439-450, 2013.

[22] W. Homsomba, T. L. Yip, H. Yang, and X. Fu, "Regional cooperation and management of port pollution," Maritime Policy and Management, vol. 40, no. 5, pp. 451-466, 2013.

[23] Y. T. Chang, "Environmental efficiency of ports: a data envelopment analysis approach," Maritime Policy and Management, vol. 40, no. 5, pp. 467-478, 2013.

[24] R. H. Chiu and I. C. Lai, "Green port measures: empirical case in Taiwan," in Proceedings of the Eastern Asia Society for Transportation Studies, vol. 8, pp. 1-15, The Eastern Asia Society for Transportation Studies, Jeju, Republic of Korea, June 2011.

[25] T. L. Saaty, "A scaling method for priorities in hierarchical structures," vol. 15, no. 3, pp. 234-281, 1977.

[26] T. L. Saaty, The Analytic Hierarchy Process, McGraw-Hill International Book, New York, NY, USA, 1980.

[27] C.-C. Chou and K.-W. Yu, "Application of a new hybrid fuzzy AHP model to the location choice," Mathematical Problems in Engineering, vol. 2013, Article ID 592138, 12 pages, 2013.

[28] G. Kabir and M. A. A. Hasin, "Comparative analysis of AHP and fuzzy AHP models for multicriteria inventory classification," International Journal of Fuzzy Logic Systems, vol. 1, no. 1, pp. 116.

[29] S. H. Ghodsypour and C. O'Brien, "A decision support system for supplier selection using an integrated analytic hierarchy process and linear programming," International Journal of Production Economics, vol. 56-57, pp. 199-212, 1998.

[30] L. A. Zadeh, "Fuzzy sets," Information and Computation, vol. 8, pp. 338-353, 1965.

[31] J. J. Buckley, "Fuzzy hierarchical analysis," Fuzzy Sets and Systems, vol. 17, no. 3, pp. 233-247, 1985.

[32] A. Kaufmann and M. M. Gupta, Introduction to Fuzzy Arithmetic, Van Nostrand Reinhold, New York, NY, USA, 1991.

[33] C. K. Kwong and H. Bai, "A fuzzy AHP approach to the determination of importance weights of customer requirements in quality function deployment," Journal of Intelligent Manufacturing, vol. 13, no. 5, pp. 367-377, 2002.

[34] L. C. Leung and D. Cao, "On consistency and ranking of alternatives in fuzzy AHP," European Journal of Operational Research, vol. 124, no. 1, pp. 102-113, 2000.

[35] F. Tahriri, M. R. Osman, A. Ali, R. M. Yusuff, and A. Esfandiary, "AHP approach for supplier evaluation and selection in a steel manufacturing company," Journal of Industrial Engineering and Management, vol. 1, no. 2, pp. 54-76, 2008.

[36] JOC, “Port news: The JOC Top 50 World Container Ports," 2013, http://www.joc.com/port-news/joc-top-50-world-container -ports_20130815.html.

[37] T. L. Saaty and L. G. Vargas, The Analytic Hierarchy Process, vol. 7, Mcgraw-Hill, Ellsworth Avenue Pittsburgh, Pa, USA, 1994.

[38] T. L. Saaty and L. G. Vargas, Models, Methods, Concepts and Applications of the Analytic Hierarchy Process, Kluwer Academic Publishers, Boston Mass, USA, 2000.

[39] L. A. Zadeh, "The concept of a linguistic variable and its application to approximate reasoning. I," vol. 8, pp. 199-249, 1975.

[40] S. T. Lu, S. H. Yu, D. S. Chang, and S. C. Su, "Using the Fuzzy Linguistic preference relation approach for assessing the importance of risk factors in a software development project," Mathematical Problems in Engineering, vol. 2013, Article ID 376375, 9 pages, 2013.

[41] OECD, "Interim Report of the Green Growth Strategy: Implementing our commitment for a sustainable future," 2010, http://www.oecd.org/dataoecd/42/46/45312720.pdf. 


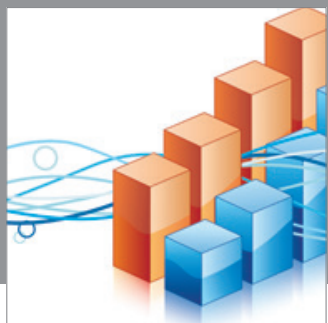

Advances in

Operations Research

mansans

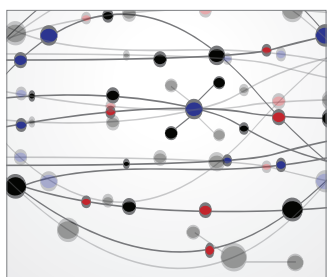

The Scientific World Journal
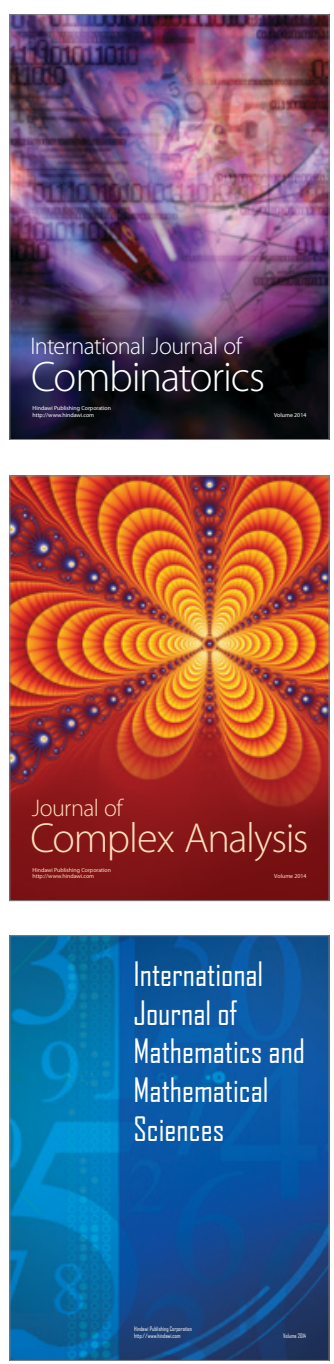
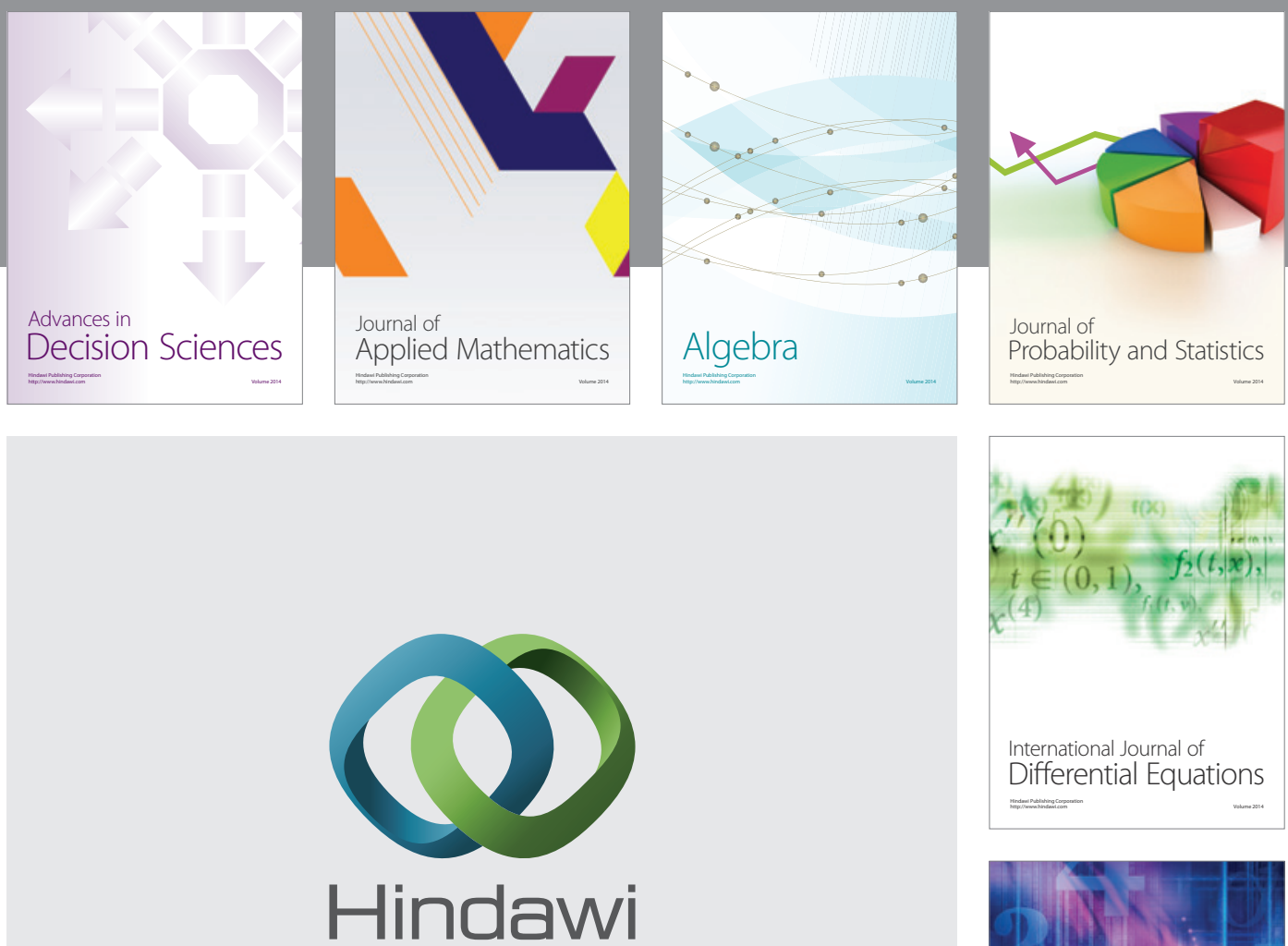

Submit your manuscripts at http://www.hindawi.com
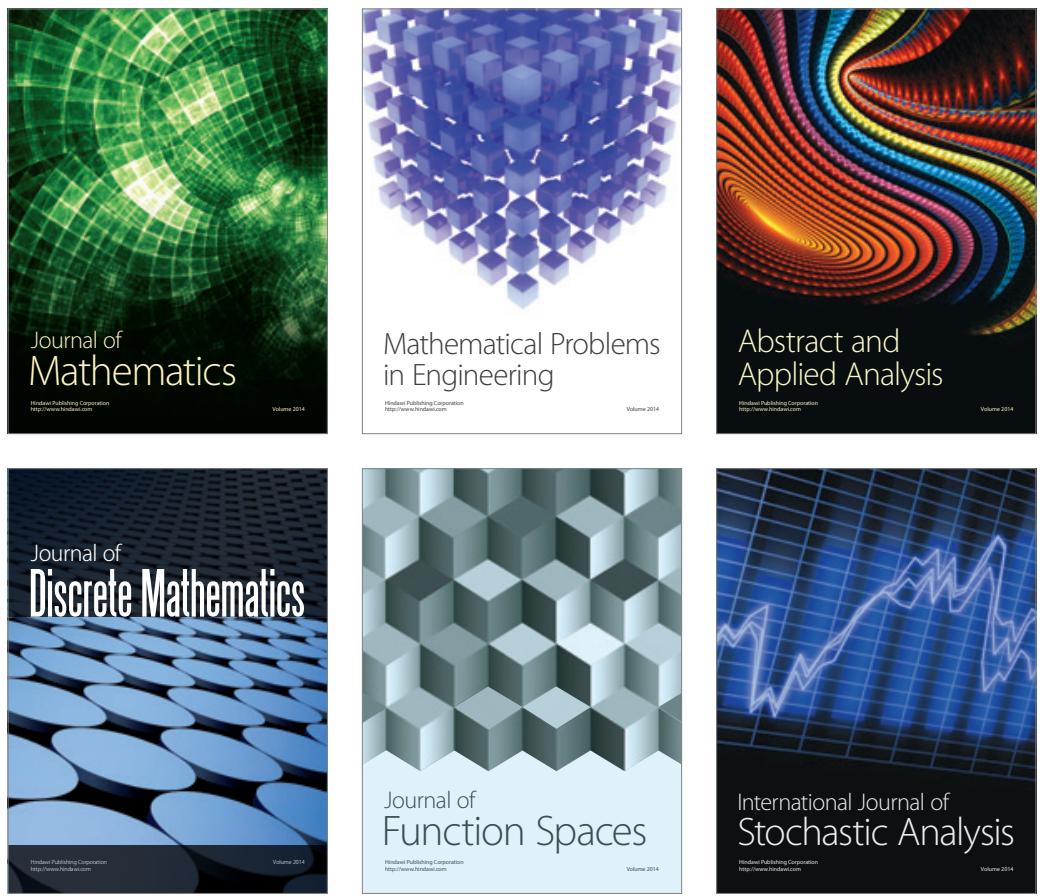

Journal of

Function Spaces

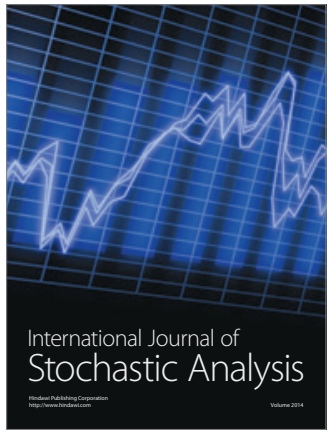

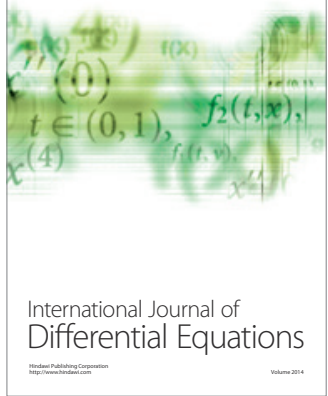
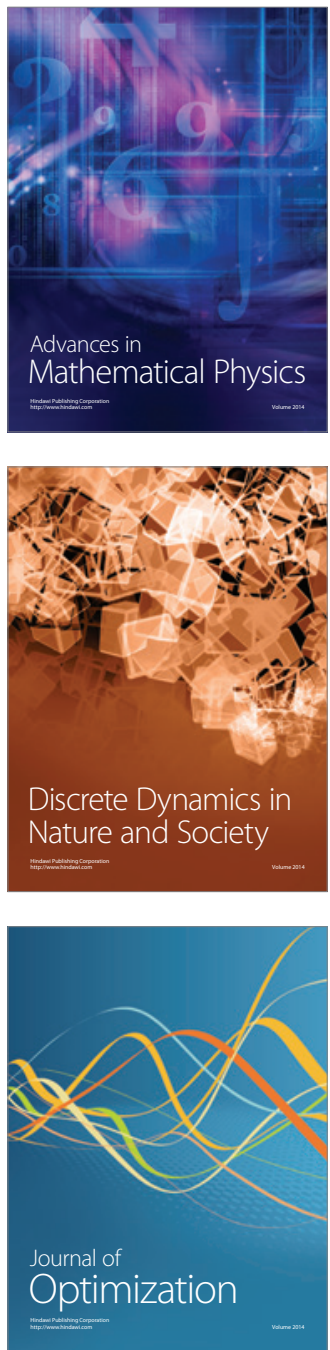